\begin{tabular}{c}
\hline Review of \\
ECONOMICS \\
and \\
INSTITUTIONS \\
\hline
\end{tabular}

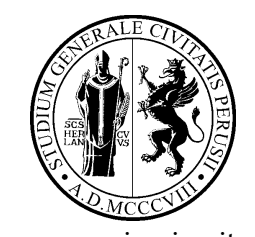

www.rei.unipg.it

\title{
The Role of Innovation in Development
}

\author{
Jan Fagerberg \\ TIK, University of Oslo \\ CIRCLE, Lund's \\ University \\ SPRU, University of \\ Sussex
}

\author{
Martin Srholec \\ CERGE-EI, Charles \\ University and Economics \\ Institute of the Academy of \\ Sciences of the Czech \\ Republic \\ TIK, University of Oslo
}

\author{
Bart Verspagen ${ }^{\bowtie}$ \\ Department of \\ Economics E UNU- \\ MERIT, Maastricht \\ University \\ TIK, University of Oslo
}

\begin{abstract}
Innovation is often seen as carried out by highly educated labour in R\&D intensive companies with strong ties to leading centers of excellence in the scientific world. Seen from this angle innovation is a typical "first world" activity. There is, however, another way to look at innovation that goes significantly beyond this high-tech picture. In this, broader perspective, innovation - the attempt to try out new or improved products, processes or ways to do things - is an aspect of most if not all economic activities. In this sense, innovation may be as relevant in the developing part of the world as elsewhere. Section two discusses the existing theoretical and empirical literature on the subject. An important conclusion is that to be able to exploit technology to their own advantage, developing countries need to develop the necessary capabilities for doing so. The third section of the paper, therefore, discusses ways to identify and measure capabilities at the national level, while section four focuses on recent attempts to survey innovation activity in firms. The final section summarizes the main lessons.
\end{abstract}

JEL classification: 014, 019, 031, 033, 040

Keywords: innovation, capability, development, developing countries

We thank Adam Szirmai, Bronwyn Hall, Nathan Rosenberg and Ezequiel Tacsir for comments to earlier drafts. The usual disclaimer applies.

$\square$ Corresponding author. Address: Department of Economics, Maastricht University, PO Box 616, NL-6200 MD Maastricht, The Netherlands.

(Email: b.verspagen@maastrichtuniversity.nl )

\section{Recommended Citation}

Fagerberg, J., Srholec, M., Verspagen, B. (2010). The Role of Innovation in Development. Review of Economics and Institutions, 1 (2), Article 2. doi: 10.5202/rei.v1i2.2.

Retrieved from http://www.rei.unipg.it/rei/article/view/15 


\section{Introduction}

One popular perception of innovation, that one meets in media every day, is that has to do with developing brand new, advanced solutions for sophisticated, well-off customers, through exploitation of the most recent advances in knowledge. Such innovation is normally seen as carried out by highly educated labour in R\&D intensive companies, being large or small, with strong ties to leading centers of excellence in the scientific world. Hence innovation in this sense is a typical "first world" activity.

There is, however, another way to look at innovation that goes significantly beyond the high-tech picture just described. In this broader perspective, innovation - the attempt to try out new or improved products, processes or ways to do things - is an aspect of most if not all economic activities (Kline and Rosenberg, 1986; Bell and Pavitt, 1993). It includes not only technologically new products and processes but also improvements in areas such as logistics, distribution and marketing. Moreover, the term innovation may also be used for changes that are new to the local context, even if the contribution to the global knowledge frontier is negligible. In this, broader sense, innovation may be as relevant in the developing part of the world as elsewhere.

The question of how technology and innovation influence economic development is a controversial issue (Fagerberg and Godinho, 2004; Fagerberg et al., 2010). In section 2 of this paper we discuss the literature that has emerged on this issue from the 1950s onwards. A natural starting point is the neoclassical growth theory developed by Robert Solow (1956) according to which technology may be assumed to be a so-called "public good" and catch up and convergence in the global economy should be expected to be relatively automatic (and quick). However, writers from several other strands, such as economic historians, with Alexander Gerschenkron (1962) as the prime example, or economists inspired by the revival of interest in Joseph Schumpeter's works, have been much less optimistic in this regard. According to these writers, there is nothing automatic about technological catch up. It requires considerable effort and organizational and institutional change to succeed (Ames and Rosenberg, 1963). A central theme in the literature on the subject concerns the various "capabilities" that firms, industries and countries need to generate in order to escape the low development trap. In section 2 of this paper we explore the burgeoning literature that has emerged on this issue.

Until recently there has been relatively little information available suited for exploring the relationship between innovation and diffusion of technology on the one hand, and economic development on the other. But during the last few decades, national governments and international organizations started to devote more efforts to collect statistics on factors 
relevant for innovation and diffusion, and various attempts have been made to capitalize on these investments to produce indicators of the technological capabilities of countries, including the developing ones. We consider this work in section 3. However, direct information on innovation activities in firms has been scarce. But from the early 1990s some countries, mainly in Europe, started based on a broad notion of innovation to survey innovation activities in firms, and more recently such surveys have also been conducted in the developing part of the world. We explore the lessons from this on-going work in section 4 of this paper. ${ }^{1}$

\section{Taking Stock of the Literature}

Intuitively, most people easily accept the idea that knowledge and economic development are intimately related, and hence that access to knowledge should be regarded as a vital factor for developing countries. However, this is not the way development used to be explained by economists. From the birth of the so-called "classical political economy" more than two hundred years ago, economists have focused on accumulated capital per worker when trying to explain differences in income or productivity. Similarly, differences in economic growth have been seen as reflecting different rates of capital accumulation. Closer to our own age, Robert Solow adopted this perspective in his so-called "neoclassical growth theory" (Solow, 1956). In this model, productivity growth results from increases in the amount of capital that each worker is set to operate. But by assumption, as capital per worker increases, the marginal productivity of capital declines, and with it the scope for further in-creases in the capital-labour ratio. Ultimately, the model predicts, productivity growth will cease.

To allow for long-run growth in GDP per capita, Solow added an exogenous term, labelled "technological progress". In this interpretation, technology - or knowledge - is a "public" good, i.e., something that is accessible for everybody free of charge. Subsequent research based on the neoclassical perspective took it for granted that if technology - or knowledge - is freely available in, say, the USA, it will be so at the global level as well. On this assumption the model predicts that, in the long run, GDP per capita in all countries will grow at the same, exogenously determined rate. The only factor left within this framework that could possibly explain differences in per capita growth across countries is socalled "transitional dynamics": since initial conditions generally differ, countries may grow at different rates in the process towards long-run

\footnotetext{
${ }^{1}$ For a more extensive treatment of many of the issues dealt with in this paper see Fagerberg et al. (2010).
} 
equilibrium, with poorer countries growing faster than the richer ones, leading to so called "convergence" in the global economy. However, this central prediction of theory was shown not to be consistent with the facts (Landes, 1998; Islam, 2003).

The first systematic attempts to relate differences in economic development to differences in knowledge (or technology) did not come from economics proper but from economic historians (Gerschenkron, 1962; Abramovitz, 1986). Rather than something that exists in the public domain and can be exploited by anybody everywhere free of charge, technological knowledge is in this tradition seen as deeply rooted in the specific capabilities of private firms and their networks/environments, and hence not easily transferable. Compared with the traditional neoclassical growth theory discussed earlier these writers paint a much bleaker picture of the prospects for catch-up and convergence; there is nothing automatic about catch up: it requires a lot of effort and capability-building.

The economic historian Alexander Gerschenkron set the stage for much of the subsequent literature (Gerschenkron, 1962). Although the technological gap between a frontier country and a laggard represents "a great promise" for the latter, a potential for high growth through imitating frontier technologies, there are also various problems that may prevent backward countries from reaping the potential benefits to the full extent. Because of this, Gerschenkron argued, late-comers had to develop new institutional instruments for overcoming these obstacles, above all in the financial sector, "instruments for which there was little or no counterpart in an established industrial country" (ibid, p. 7). Although Gerschenkron's work is often associated with his focus on investment banks, which he saw as critical in mobilizing resources for development, as pointed out by Shin (1996), it is possible to see his writings as an attempt to arrive at a more general understanding of the conditions for catch-up, focusing on the instruments - or capabilities to use a more recent term - that need to be in place for successful catch-up to take place.

Moses Abramovitz, arguing along similar lines as Gerschenkron, also placed emphasis on the potential for catch-up by late-comers. He suggested that differences in countries' abilities to exploit this potential might to some extent be explained by differences in so-called "social capability". ${ }^{2}$ These are some of the aspects that he considered to be particularly relevant (Abramovitz 1986, 1994a, b):

- $\quad$ technical competence (level of education)

- experience in the organization and management of large scale enterprises

2 The term "social capability" comes from Ohkawa and Rostovsky (1974). 
- financial institutions and markets capable of mobilizing capital on a large scale

- the stability of government and its effectiveness in defining (enforcing) rules and supporting economic growth

- honesty and trust

A related concept that has become popular in the applied literature on growth and development is "absorptive capacity". The term is not new, in development economics it has been used for a long time as the ability of a developing country to absorb new investments (Adler, 1965; Eckaus, 1973). However, as the role of knowledge for growth and development became more widely recognized, it came to be associated with the ability to absorb knowledge. Wesley Cohen and Daniel Levinthal, in an influential contribution (Cohen and Levinthal, 1990), defined it as "the ability of a firm to recognize the value of new, external information, assimilate it and apply it to commercial ends" (ibid p. 128). Cohen and Levinthal saw absorptive capacity as dependent on the firm's prior related knowledge, which was assumed to reflect its cumulative R\&D. Although the focus of Cohen and Levinthal was on firms, many of the same considerations apply, as emphasized above, at more aggregate levels, such as regions or countries (Keller, 1996; Eaton and Kortum, 1999; Griffith et al., 2004), and the concept has continued to be used as such levels as well.

While much of the early literature focused mainly on evidence from Europe and the United States, from the 1970s onwards several studies on the relationship between technological capability (and/or innovation) and catch-up (or lack of such) in other parts of the world emerged. One case which received much attention was the rise of Korea from being one of the poorest countries in the world to a first world technological powerhouse in just three decades. Linsu Kim, who made the authoritative study on the subject, used the concept "technological capability" as an analytical device to interpret the Korean evidence (Kim, 1980). He defined it as "the ability to make effective use of technological knowledge in efforts to assimilate, use, adapt and change existing technologies. It also enables one to create new technologies and to develop new products and processes..." (Kim 1997 , p. 4). Hence, the concept includes not only organized R\&D, which arguably is a small activity in many developing countries, but also other capabilities needed for the commercial exploitation of technology. ${ }^{3}$

Kim's analyses were based on lessons from how Korean electronics firms, such as Samsung, gradually upgraded from a passive role of implementing imported technology, to a more active role of introducing

\footnotetext{
${ }^{3}$ As the reader may have observed, the definition of technological capabilities by Kim is quite similar to that of absorptive capacity by Cohen and Levinthal (1990) and Kim (1997) uses the two concepts interchangeably.
} 
incremental improvements, and eventually ventured into the forefront of innovation-based competition. It has become common in the literature (see, e.g., Dahlman et al., 1987; Kim, 1997; Romijn, 1999) to consider three aspects of technological capability: production capability, investment capability and innovation capability. Production capability is needed to operate productive facilities efficiently and to adapt production to changing market circumstances. Investment capability is needed to establish new productive facilities and adjust project designs to suit the circumstances of the investment. Finally, innovation capability is required to create new technology, e.g., develop new products or services that better meet the specific requirements of the market.

The concept has been used in a large number of studies at various levels of aggregation. Initially many studies concentrated on understanding the rapid technological catching up in East Asia (Kim, 1980, 1997; Fransman, 1982; Amsden, 1989; Hobday, 1995) and the lack of it elsewhere, such as in Latin America (Teitel, 1981; Katz, 1984; Fransman and King, 1984), India (Lall, 1987) or the former centrally planned economies (Hanson and Pavitt, 1987). Although initially developed for firms, the concept has also been applied to whole industries or countries. Sanjaya Lall, in a survey (Lall, 1992), emphasized three aspects of "national technological capability" as he phrased it: the ability to muster the necessary (financial) resources and use them efficiently; skills, including not only general education but also specialized managerial and technical competence; and what he called "national technological effort", which he associated with R\&D, patents and technical personnel. He noted that national technological capability does not only depend on domestic technological efforts but also foreign technology acquired through imports or FDI. Lall also made a distinction between technological capabilities proper and their economic effects. These effects, he noted, did also depend on the incentives that economic agents face whether resulting from political decision making (e.g., governance) or embedded in more longlasting institutions (the legal framework, for example). This reasoning is of course very similar to that of Abramovitz. Hence, potentially there is a considerable overlap between the concepts of technological and social capabilities: both include aspects related to skill formation, finance and governance.

The observation that technological and social factors interact in the process of economic development might also be taken as supporting the view that a broader, more systemic approach that takes such interactions into account is required. Such concerns led during the 1980s and 1990s to the development of a new systemic approach to the study of countries' abilities to generate and profit from technology, the so-called "national innovation system" approach. The concept, first used in public by 
Christopher Freeman in an analysis of Japan (Freeman, 1987), soon became a popular analytical tool for researchers who wanted to get a firmer grasp on the interaction processes underlying a country's technological and economic development (Lundvall, 1992; Nelson, 1993; see Edquist, 2004 for an overview). Organizations such as the OECD, the EU and the UN intensified their efforts to provide relevant statistics with which performance along these lines could be assessed.

The successful catch-up of a number of "newly industrializing" countries in the 1970s and 1980s also served as inspiration for the development of new perspectives on the dynamics of the global economy that placed the development of appropriate technological activities (or capabilities) at the core of the analysis (Fagerberg, 1987, 1988; Dosi et al., 1990; Verspagen, 1991; for an overview see Fagerberg and Godinho, 2004). Following this approach, catch-up or convergence is by no means guaranteed. It depends on the balance of innovation and imitation, how challenging these activities are and the extent to which countries are equipped with the necessary capabilities. According to Verspagen (1991), who implemented these ideas into a non-linear setting that allows for both catch-up and a "low-growth trap", poor countries with a low "social capability" are the ones at risk of being "trapped". Moreover, evidence presented in Fagerberg and Verspagen (2002) suggests that the importance of innovation for development is increasing with time.

During the 1980s and 1990s economists' interest in the possible role of knowledge (technology) for growth and development increased. On the theoretical front an important development was the emergence of the socalled "new growth theory" (Romer, 1986, 1990; Aghion and Howitt, 1992, 1998) according to which differences in economic development across countries should be understood as the outcome of differences in endogenous knowledge accumulation within (largely national) borders. Although some newly created technological knowledge may spill over from one country to another, there are according to this approach sufficient impediments to this process (being legal, such as intellectual property rights (IPRs), or more informal in nature) to secure that in most cases the lion's share of the benefits will accrue to the innovator. Hence, following this approach, long run economic growth should to a large extent be expected to depend on appropriability conditions. Moreover, the theory predicts that large countries should be expected to be more innovative, and benefit more from innovation, than small countries. According to the theory, the latter may to some extent overcome the disadvantages of scale by practicing free trade and taking a liberal stance towards international capital flows. Hence, following this approach, openness to trade and foreign investment is essential for countries that 
wish to catch up (Grossman and Helpman, 1991; Coe and Helpman, 1995; Coe et al., 1997).

Although it is widespread view that openness to trade and foreign direct investments is a positive factor for growth, the evidence supporting this conclusion is not strong (Rodríguez and Rodrik, 1999; Görg and Greenaway, 2004). With respect to FDI, since most channels through which FDI may generate spillovers are hard to observe directly, empirical studies mostly estimate productivity equations with FDI among the independent variables. Wooster and Diebel (2006) provide an overview of 32 econometric studies of the impact of FDI in developing countries. They find positive effects of spillovers in around one half of the included observations.

Recent econometric work on the subject increasingly use panel data, but according to Wooster and Diebel, this does not change the results significantly. In contrast, Görg and Strobl (2001), in a similar meta-study for a sample of both developed and developing nations, report that using panel data mostly yields negative or insignificant spillovers.

Trade is another way through which developing countries may benefit from knowledge flows. The study by Coe et al. (1997) estimated of a production function in which "imported R\&D", e.g., R\&D performed in the exporting country but embodied in exports, is assumed to have an impact on growth in the importing country. They report that, in 1990, R\&D spillovers from developed to developing nations through trade were worth about 22 billion US\$, which would be comparable to about half of the total global development aid at that time. However, the methodology adopted by Coe et al. has been criticized on the ac-count that the trade related scheme may be spurious (Keller, 2004). Other studies, including trade related measures in growth regressions, have yielded mixed results at best (Rodrik et al., 2004; Fagerberg and Srholec, 2008).

\section{Measuring Capabilities}

As is evident from the preceding section, conceptual work on the role of "capabilities" and "innovation systems" for development has flourished recently. However, trying to put numbers on such concepts may be a difficult exercise, as Archibugi and Coco (2005) point out. Still there have been some attempts in that direction. For example, Furman et al. (2002) and Furman and Hayes (2004) have suggested measuring a country's innovation system (or its "innovative capacity" as they put it) through the number of patents it generates and found that there are large differences in this respect across countries at similar levels of income. However, patents refer to inventions, not innovations, and are used much more 
intensively in some industries than others. In fact, the global novelty requirement associated with patents implies that minor innovations/adaptations, which arguably make up the bulk of innovative activity world-wide, will not be counted since these are simply not patentable. Thus, for countries below the technology frontier, and developing countries in particular, most of their innovative activities would get unrecognized by this approach. Most attempts to measure national technological capabilities or innovation systems in developing countries therefore try to take into account more information than just patents.

Table 1 - Measuring Capabilities

\begin{tabular}{|c|c|}
\hline Dimension & Measure \\
\hline $\begin{array}{l}\text { Science, research and } \\
\text { innovation }\end{array}$ & $\begin{array}{l}\text { Scientific publications, patents, R\&D (total/business), innovation } \\
\text { counts }\end{array}$ \\
\hline Openness & $\begin{array}{l}\text { Openness to trade, foreign direct investment, research } \\
\text { cooperation/alliances with foreign partners, technology licensing, } \\
\text { immigration }\end{array}$ \\
\hline $\begin{array}{c}\text { Production } \\
\text { quality/standards }\end{array}$ & $\begin{array}{c}\text { International (ISO) standards, total quality management (TQM), lean } \\
\text { production, just-in-time }\end{array}$ \\
\hline ICT infrastructure & Telecommunications, internet, computers \\
\hline Finance & Access to bank credit, stock-market, venture capital \\
\hline Skills & $\begin{array}{l}\text { Primary, secondary and tertiary education, managerial and technical } \\
\text { skills }\end{array}$ \\
\hline Quality of governance & $\begin{array}{c}\text { Corruption, law and order, independence of courts, property rights, } \\
\text { business friendly regulation }\end{array}$ \\
\hline Social values & $\begin{array}{l}\text { Civic activities, trust, tolerance, religious ethics, attitudes towards } \\
\text { technology and science }\end{array}$ \\
\hline
\end{tabular}

While commendable taking into account more information also represents a challenge, both with respect to data availability and in terms of method. Such exercises easily run into problems because, typically, most developed market economies figure prominently among those with good coverage, while developing countries often lack data on many potentially useful indicators. Based on the preceding discussion Table 1 presents an overview of various factors that have been identified in the literature as being particularly relevant for the measurement of technological and social capabilities along with examples of possible empirical indicators.

As discussed earlier, the concept of technological capability refers to the ability to develop, search for, absorb and exploit knowledge commercially. An important element of this is what Kim (1997) termed "innovation capability." There are several data sources that capture different aspects of this. For example, the quality of a country's science base, on which invention and innovation activities to some extent depend, may be reflected in articles published in scientific and technical journals. Research 
and development (R\&D) expenditures measure some (but not all) resources that are used for developing new products or processes, while patents count (patentable) inventions coming out of that process. However, R\&D data are not available for many developing countries. Patent data, on the other hand, are available for all countries but as noted above this gives only a very partial view of what we wish to measure. Firms' own judgments about their innovativeness (innovation counts) is another possible source of information but such data are only available for a relatively small number of countries and a limited time span (see, however, the next section).

Openness (or interaction) across country borders may as discussed earlier facilitate technology transfer (spillovers) and stimulate innovation. The applied literature on the subject has mostly focused on four channels of technology transfer across country borders: trade, foreign direct investment, migration and licensing (for overviews see Cincera and Van Pottelsberghe, 2001; Keller, 2004, 2010). Some of these data sources are in scarce supply for developing countries, with predictable consequences for the available research on this issue.

Another important aspect of technological capability mentioned by Kim (1997) is "production capability." A possible indicator of this might be the adoption of quality standards (ISO 9000). Although ISO certification is mainly procedural in nature, it is increasingly seen as a requirement for firms supplying high quality markets, and is therefore likely to reflect a high emphasis on quality in production. Moreover, although earlier studies such as Lall (1992) did not place much emphasis on capabilities in ICT, nowadays a well-developed ICT infrastructure must be regarded as a critical factor for a country that wishes to catch up. Possible indicators reflecting ICT use may be number of personal computers, internet users and fixed/mobile phone subscribers. These indicators are available for most countries.

The important role that a country's financial system may play in mobilizing resources for catching-up was pointed out already by Gerschenkron, Abramovitz and Lall. Kim included this in his definition of "investment capability." It is also emphasized by a host of recent research (see, e.g., King and Levine, 1993; Levine, 1997; Levine and Zervos, 1998). Authors in the capability literature attached a qualitative dimension to this that is difficult to capture with the available data. What we can measure is the (quantitative) development of the financial sector of a country, for example as reflected in the amount of credit (to the private sector) or by capitalization of companies listed in domestic capital markets.

A different set of factors, emphasized by for example Abramovitz and Lall, and for which there is also solid support in the literature, relates to education and skills (for an overview see Krueger and Lindahl, 2001). Both 
Abramovitz and Lall were especially concerned about specialized managerial and technical skills but this is again an example of information that is hard to come by. What is available for most countries are more basic education statistics such as the literacy rate, the teacher-pupil ratio and the rates of enrolment at different levels.

The importance of governance and institutions, furnishing economic agents with incentives for creation and diffusion of knowledge, is generally acknowledged in the literature. Although such factors often defy "hard" measurement, especially in a broad cross-country comparison, there exist some survey-based measures, often collected by international organisations, that may throw some light on these issues. For example, there now exists survey data reflecting how easy it is to set up and operate a business, the extent to which law and order prevails, independence of courts, whether (intellectual) property rights are enforced, political stability or how widespread corruption is conceived to be (Djankov et al., 2002 and 2003; Kaufmann et al., 2003; Botero et al., 2004; La Porta et al., 2004; Park, 2008; World Bank, 2009).

However, the impact of government's actions on innovation activities and development outcomes may as pointed out by Abramovitz also depend on the prevailing social values in society such as, for example, tolerance, honesty and trust. Such values, facilitating socially beneficial, cooperative activities, are often seen as expressions of so-called "social capital" (Putnam, 1993; for an overview see Woolcock and Narayan, 2000). The fact that the type of factors taken up by the literature on social capital may matter for economic development is widely accepted. The problem is rather how to measure it. One possible source of information that has been exploited to throw some light on the issue is the "World Value Survey" (World Values Survey Association, 2006). However, the limited time and country coverage of these data has, until recently at least, precluded its extension to a sizeable part of the developing world.

Given the relatively large number of potentially useful indicators there is obviously a lot of information to exploit when attempting to measure capabilities. One key challenge is how to combine this rich information into a smaller number of dimensions (e.g., capabilities) with a clear-cut economic interpretation. The most widely used approach to construct composite variables is to select relevant indicators and weigh them together using predetermined (usually equal) weights (Archibugi and Coco, 2005). The problem in this case is that the choice of weights tends to be quite arbitrary. An alternative approach, pioneered by Adelman and Morris $(1965,1967)$, uses so-called "factor analysis" to advise on questions like these. This method is based on the idea that indicators referring to the same dimension are likely to be strongly correlated, and that we may use this insight to reduce the complexity of a large data set (consisting of 
many indicators) into a small number of composite variables, each reflecting a specific dimension of variance in the data.

Fagerberg and Srholec (2008) used factor analysis on data for 115 countries and 25 indicators between 1992-2004. The analysis led to the selection of four principal factors jointly explaining about three quarter of the total variance of the set of indicators. The first (and quantitatively most important) of these loaded highly on several indicators associated with "technological capability" such as patenting, scientific publications, ICT infrastructure, ISO 9000 certifications and access to finance. However, it also correlated highly with education, so it cut across the distinction in the literature between "technological" (Kim, 1997) and "social" capabilities (Abramovitz, 1986). They suggested to interpret it as a synthetic measure of the capabilities (or "factors") influencing the "development, diffusion and use of innovations", quoting Edquist (2004)'s definition of an innovation system, hence the name "innovation system" for this factor. Fagerberg and Srholec found a very close correlation between their "innovation system variable" and economic development as reflected in GDP per capita.

Table 2 - Correlation Between Measures of National Capabilities

\begin{tabular}{|c|c|c|c|c|c|c|c|c|c|}
\hline & Indicator & Reference & $\begin{array}{l}\text { Reference } \\
\text { period }\end{array}$ & (1) & (2) & (3) & (4) & (5) & (6) \\
\hline (1) & ArCo & $\begin{array}{l}\text { Archibugi and } \\
\text { Coco (2004) }\end{array}$ & 2000 & & 0.90 & 0.93 & 0.92 & 0.85 & 0.89 \\
\hline (2) & Innovation system & $\begin{array}{l}\text { Fagerberg and } \\
\text { Srholec (2008) }\end{array}$ & $2000-04$ & 115 & & 0.74 & 0.85 & 0.89 & 0.96 \\
\hline (3) & $\begin{array}{c}\text { Technology } \\
\text { competitiveness }\end{array}$ & $\begin{array}{l}\text { Fagerberg et } \\
\text { al. (2007) }\end{array}$ & 2002 & 90 & 79 & & 0.84 & 0.53 & 0.72 \\
\hline (4) & $\begin{array}{c}\text { Capacity } \\
\text { competitiveness }\end{array}$ & $\begin{array}{l}\text { Fagerberg et } \\
\text { al. (2007) }\end{array}$ & 2002 & 90 & 79 & 90 & & 0.69 & 0.87 \\
\hline (5) & SOCDEV & $\begin{array}{c}\text { Temple and } \\
\text { Johnson } \\
(1998)\end{array}$ & $1957-62$ & 73 & 57 & 53 & 53 & & 0.88 \\
\hline (6) & $\begin{array}{c}\text { Human } \\
\text { development index }\end{array}$ & UNDP (2004) & 2004 & 154 & 114 & 89 & 89 & 68 & \\
\hline
\end{tabular}

Notes: Above the diagonal is the correlation coefficient between pairs of measures and below the diagonal is for each of these pairs the number of (common) observations.

Table 2 presents a comparison of different composite variables aiming at measuring (national) technological and/or social capabilities (activities). The ArCo measure, developed by Archibugi and Coco (2004), was constructed as the average of eight different indicators reflecting various aspects of technological capability for 162 countries in the late 1980s and 1990s. The technology and capacity competitiveness indexes developed by Fagerberg et al. (2007), were developed to reflect capabilities necessary for exploration and exploitation of technology, respectively. The SOCDEV 
variable, initially developed by Adelman and Morris (1965) and later updated by Temple and Johnson (1998), is an amalgam of structural indicators, socio-economic characteristics and the development of mass communication. Finally, the Human Development Index is assumed to reflect the level of "social" development (e.g., welfare) as reflected in statistics on health and education (UNDP, 2004).

The main lesson to be drawn from Table 2 is the very close correlation between these measures. For example, the correlation coefficient between the ArCo and the Innovation System measures is 0.90. Second, there is a very close correlation between these measures and the Human development index, which to some extent is to be expected due to their overlapping nature. It is also consistent with the finding in the literature of a close relationship between technological and social capabilities (Fagerberg and Srholec, 2008).

The finding that economic development and capability building go hand in hand is suggestive. But correlation, it may be noted, is in itself no proof of causation. Fagerberg and Srholec (2008) provided some evidence (in the form of econometric tests) supporting the proposition that capability building affects development positively. However, since many of the relevant data sources used to measure capability-building exist only for a few years (and in some cases for a single year only), there is limited scope for causality testing and the possibility that economic development in some sense affects capability building (or some aspects of it) positively cannot be excluded.

\section{Innovation in Developing Country Firms}

In this section we move from the macro to the micro level; from the technological capabilities of countries to the innovation activities in firms. Figueiredo (2006), in a recent survey, points out that our knowledge about innovation in developing country firms has been constrained by the fact that the available evidence has been overwhelmingly qualitative in character, creating problems for comparison and generalization. However, from the early 1990s onwards efforts were made to collect more information on innovation activities of firms through surveys based on the so-called Oslo Manual (Smith, 2004). In the beginning these surveys were mostly confined to member states of the European Community, hence the label "Community Innovation Surveys" (CIS), but more recently a number of other countries, including some developing ones, have started to collect the same type of information (Jaramillo et al., 2001; UNU-INTECH, 2004; Blankley et al., 2006). These efforts resulted among other things in the creation of the so-called Bogota Manual for how to carry out innovation 
surveys in developing countries (Jaramillo et al., 2001). The authors of this manual argued that the original Oslo-approach to innovation was too narrow and needed to be broadened to take into account factors such as organisational change, training, use of ICTs, etc. in a better way. These concerns subsequently led to revisions of the Oslo Manual, the third edition of which includes a separate appendix on measurement of innovation in developing countries (OECD, 2005) based to a large extent on the Bogota Manual.

Table 3 - Innovation Surveys in Catching-up Economies

\begin{tabular}{|c|c|c|c|c|c|c|}
\hline & \multirow{2}{*}{$\begin{array}{c}\text { GDP per } \\
\text { capita } \\
\text { (PPP) }\end{array}$} & \multirow[t]{2}{*}{$\begin{array}{l}\text { Response } \\
\text { rate }\end{array}$} & \multirow[t]{2}{*}{$\begin{array}{l}\text { Number of } \\
\text { respondents }\end{array}$} & \multirow[t]{2}{*}{$\begin{array}{l}\text { Reference } \\
\text { period }\end{array}$} & \multicolumn{2}{|c|}{$\begin{array}{l}\% \text { of firms with new or } \\
\text { significantly improved }\end{array}$} \\
\hline & & & & & Product & Process \\
\hline Slovenia & 18,405 & $88 \%$ & 2,960 & $02-04$ & 20 & 22 \\
\hline Korea* & 18,271 & $61 \%$ & .. & $02-04$ & 36 & 23 \\
\hline Taiwan & 18,247 & $34 \%$ & 3,356 & $98-00$ & 28 & 33 \\
\hline Czech Rep. & 17,634 & $74 \%$ & 6,188 & $03-05$ & 27 & 30 \\
\hline Hungary & 14,836 & $77 \%$ & 3,950 & $02-04$ & 14 & 13 \\
\hline Slovakia & 12,803 & $73 \%$ & 2,195 & $02-04$ & 15 & 17 \\
\hline Estonia & 11,892 & $79 \%$ & 2,201 & $02-04$ & 37 & 33 \\
\hline Poland & 11,608 & $87 \%$ &.. & $02-04$ & 15 & 19 \\
\hline Argentina* & 11,421 & $76 \%$ & 1,627 & $02-04$ & 39 & 37 \\
\hline Lithuania & 11,042 & $94 \%$ & 1,639 & $02-04$ & 17 & 20 \\
\hline Latvia & 10,101 & .. & 2,990 & $02-04$ & 9 & 10 \\
\hline South Africa & 9,290 & $37 \%$ & 979 & $02-04$ & 42 & 35 \\
\hline Chile* & 9,103 & $15 \%$ & 706 & 99-01 & 43 & 40 \\
\hline Russia & 9,101 &.. &.. & 04 & \multicolumn{2}{|c|}{ Less than $10 \%$} \\
\hline Mexico* & 9,038 & $69 \%$ & 1,515 & $99-00$ & 27 & 24 \\
\hline Malaysia* & 8,496 & $19 \%$ & 749 & 00-01 & 32 & 27 \\
\hline Uruguay* & 7,981 & $98 \%$ & 814 & 01-03 & 23 & 26 \\
\hline Turkey & 7,460 & .. & .. & 04-06 & 22 & 23 \\
\hline Bulgaria & 7,212 & $80 \%$ & 13,710 & $02-04$ & 14 & 8 \\
\hline Brazil & 7,196 & .. & 10,600 & 01-03 & 20 & 27 \\
\hline Romania & 7,193 & $78 \%$ & 9,180 & 02-04 & 15 & 18 \\
\hline Thailand & 7,091 & $43 \%$ & 2,582 & 03 & 6 & 5 \\
\hline Tunisia & 6,812 & $79 \%$ & 586 & $02-04$ & 51 & 49 \\
\hline China* & 6,043 & $82 \%$ & 31,436 & 04-06 & 25 & 25 \\
\hline
\end{tabular}

Notes: $\left({ }^{*}\right)$ Manufacturing firms only

Source: World Bank (2008), national statistical offices and other sources.

According to the third edition of the Oslo Manual (OECD, 2005, p. 46) "an innovation is the implementation of a new or significantly improved product (good or service), or process, a new marketing method, or a new organisational method in business practices, workplace organisation or external relations." Arguably, this broad definition is close to the one originally offered by Schumpeter (1934). However, in the CIS survey it suffices for the innovation to be new to the firm, it does not necessarily have to be new to the market or to the world as a whole. Thus innovation 
in this sense includes activities that Schumpeter would have classified as imitation. ${ }^{4}$

This is consistent with the emphasis in recent literature on incremental innovation and the close relationship between innovation and diffusion, but from a comparative perspective this entirely subjective definition of innovation may also create problems, because something that would qualify as an innovation in one context may not do so in another.

Table 3 presents main results from innovation surveys in countries in the process of development. We have chosen to include some countries that have managed to substantially reduce the difference vis-à-vis the developed part of the world, hence the term "catching-up economies". In cases where several surveys have been conducted we chose the most recent. It should be emphasized, however, that the figures need to be treated with some caution, because of differences in questions, length of the reference period and sampling (UNU-INTECH, 2004). Nevertheless, the result that innovation is quite frequent also in the developing world seems to be supported.

Another source of information on innovation in developing countries that deserves mentioning here is the Productivity and Investment Climate Survey (PICS) of the World Bank. In this survey, which covers around 100,000 firms in more than 100 (mostly) developing countries, firms were asked about various aspects of their business activities, including innovation and learning (World Bank, 2003).

Table 4 summarizes some of the results with respect to innovation. Since we are concerned about the quality of the data, we use only datasets including about one thousand (or more) observations. Another concern is that despite the fact that these surveys are coordinated by the World Bank, the questions about innovation have changed between different waves of the questionnaire. To control for these differences, we group together countries with similar questionnaires.

The overall impression from these data is, as before, that innovation is a quite frequent phenomenon in developing countries. ${ }^{5}$ Similarly to the CIS surveys, innovations in the PICS survey are new to the firm, not necessarily to the market or to the world as a whole. However, since firms in developing countries can benefit from imitation of technologies already in use in the developed part of the world, they may - everything else

\footnotetext{
${ }^{4}$ See Fagerberg $(2003,2004)$ for an extended discussion of the Schumpeterian contribution and different definitions of innovation.

${ }^{5}$ An intriguing finding is that, with an exception for China, the propensity to answer positively is much higher in the PICS than in the CIS surveys. We are not aware of any attempt to explain this result, which occurs in spite of the fact that the definitions are not all that different. The major difference between the two surveys is that the CIS questionnaire is more elaborate and the term "innovation" is used.
} 
equal - be more likely to introduce "new to the firm" innovations than their more advanced counterparts in Europe or elsewhere. Probably much of this is related to diffusion of advanced technology from abroad "innovation through imitation" as Kim (1997) puts it. But as pointed out above this does not at all make these innovations less relevant economically.

Table 4 - Evidence on Innovation from Productivity and Investment Climate Surveys Organized by the World Bank.

\begin{tabular}{|c|c|c|c|c|c|}
\hline \multirow{2}{*}{ Country } & \multirow{2}{*}{ GDP per capita (PPP) } & \multirow{2}{*}{ Number of respondents } & \multirow{2}{*}{$\begin{array}{c}\text { Reference } \\
\text { period }\end{array}$} & \multicolumn{2}{|c|}{$\%$ of firms that innovated } \\
\hline & & & & Product & Process \\
\hline \multicolumn{6}{|c|}{ Questionnaire version 1: } \\
\hline China & 2,496 & 1,498 & $98-00$ & 21 & 30 \\
\hline China & 2,787 & 2,375 & $99-02$ & 24 & 33 \\
\hline \multicolumn{6}{|c|}{ Questionnaire version 2: } \\
\hline Poland & 12,488 & 968 & $02-04$ & 35 & 34 \\
\hline Turkey* & 9,302 & 1,323 & $03-04$ & 36 & 42 \\
\hline Brazil* & 7,883 & 1,640 & $97-02$ & 68 & 68 \\
\hline Thailand* & 7,224 & 1,042 & $05-06$ & 48 & 46 \\
\hline Thailand* & 5,933 & 1,385 & $01-02$ & 50 & 52 \\
\hline Egypt* & 4,332 & 977 & $02-03$ & 15 & 11 \\
\hline Egypt* & 4,687 & 995 & $04-05$ & 19 & .. \\
\hline Morocco* & 3,107 & 831 & $00-02$ & 25 & 35 \\
\hline India* & 2,004 & 2,240 & $03-04$ & 40 & 16 \\
\hline Vietnam* & 1,942 & 1,149 & $03-04$ & 44 & 45 \\
\hline \multicolumn{6}{|c|}{ Questionnaire version 3: } \\
\hline Mexico* & 11,142 & 1,119 & $03-05$ & 35 & 34 \\
\hline Ukraine & 6,048 & 848 & $05-07$ & 57 &.. \\
\hline Nigeria* & 1,736 & 945 & $04-06$ & 54 & 53 \\
\hline Bangladesh* & 1,071 & 1,201 & $04-06$ & 33 & 45 \\
\hline Turkey & 10.870 & 1,148 & $05-07$ & 45 &.. \\
\hline
\end{tabular}

Stylized facts on the propensity of firms to innovate are informative but do not reveal much about factors that explain innovation in firms and the effects on performance. To handle such questions researchers have applied econometric models, and we discuss some of this work in the following. Tables 5 and 6 provide an overview of the studies taken into account here. A natural starting point is to look for variables explaining innovation, which is the question addressed by the first set of papers considered here (Table 5). The column to the far right lists the key explanatory variables taken into account. In spite of the fact that the models, samples and methods differ, the results seem to be quite robust. 
Table 6 - Estimates of the Link Between Innovation and Productivity Based on Micro Data from CIS/PICS in Catching-up Economies.

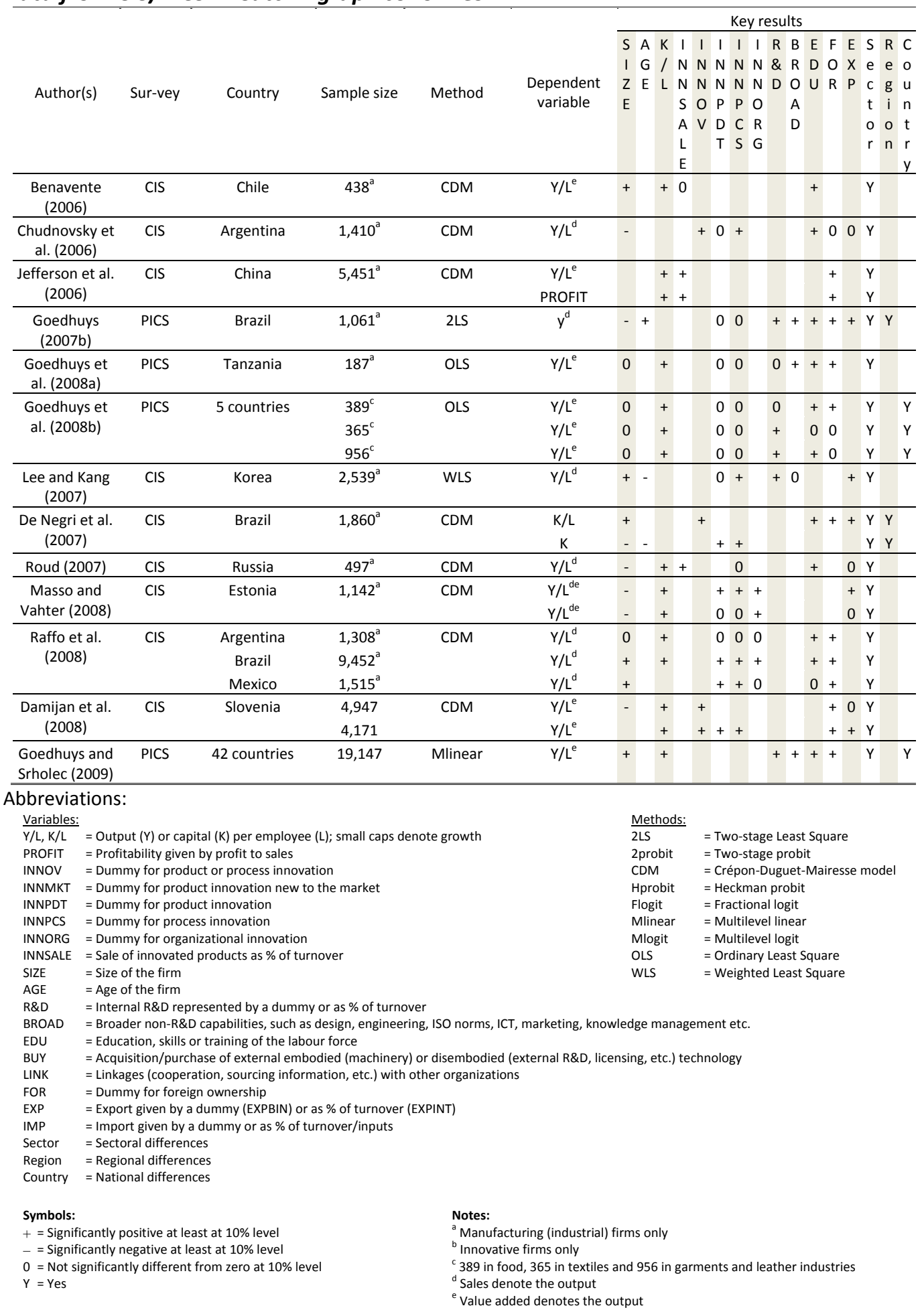


First of all, as in developed countries, large firms are more innovative than smaller ones (but the latter tend to report relatively higher proportion of sales of innovative products). The age of the firm, on the other hand, is not a conducive factor for innovation. Firms with more well-developed technological capabilities, broadly defined, are clearly more innovative. The same goes for firms that use external sources of knowledge intensively and interact actively with customers, suppliers and other actors in the innovation system. These positive results do not carry over to measures of foreign ownership, which did not come out as significantly correlated with innovation in around one half of the cases considered, and this also holds for the relationship between exports and innovation.

Another important question considered in the literature concerns the impact of innovation on firm performance (Table 6). A widely used econometric approach for assessing this effect is the so-called CréponDuguet-Mairesse (CDM) model (Crépon et al., 1998), which in a sequential way considers links between R\&D, innovation and labour productivity. Using CIS type data this framework has been applied to at least eight developing countries. Statistically significant effects of at least one of the innovation variables have been confirmed in most cases.

Finally, we examine how differences in contexts to which firms belong have been taken into account. Information on this is included in Tables 5 and 6 in the last three sub-columns under "Key results". As is evident from the tables all of the studies controlled in one way or another for sectorial differences but only some considered territorial differences. Using a multilevel model on PICS data from 28 countries, mostly developing, Srholec (2008) demonstrated that variables representing the national framework conditions contributed to the explanation of the likelihood of firms to innovate. Similarly, Goedhuys and Srholec (2009), in a follow-up study based on evidence from PICS in 42 countries, showed that various national factors influenced firms' abilities to benefit from their own technological capabilities. Hence, national and firm level capabilities interact in the process of development.

\section{Conclusions}

Until recently most people would have considered it odd to consider innovation as an important issue for developing countries, and many probably still see it that way. This skepticism is based on the widely shared view that innovation primarily is of interest for high-tech firms in advanced environments. However, this paper argues that the "high tech" approach to innovation, which has framed much thinking and policy advice on the subject, is strongly misleading when it comes to 
understanding the relationship between innovation and development. In fact, the evidence considered in the paper shows that innovation is quite widespread among developing country firms, is associated with higher productivity and, as in the developed part of the world, is dependent on interactions with other private and public actors. This is not to say that innovations in developed and developing countries are identical in every respect but in qualitative terms innovation is found to be a powerful force of growth in both and therefore an issue that it is imperative to get a better understanding of, theoretically as well as empirically. 


\section{References}

Abramovitz, M. (1986). Catching Up, Forging Ahead, and Falling Behind. Journal of Economic History, 46 (2), 386-406.

doi:10.1017/S0022050700046209

Abramovitz, M. (1994a). The Origins of the Post-war Catch-Up and Convergence Boom. In J. Fagerberg, B., Verspagen \& N., von Tunzelman (Eds.), The Dynamics of Technology, Trade and Growth. Aldershot: Edward Elgar.

Abramovitz, M. (1994b). Catch-up and Convergence in the Postwar Growth Boom and After. In W. J., Baumol, R. R., Nelson \& E. N., Wolf (Eds.), Convergence of Productivity - Cross-national Studies and Historical Evidence (pp.86-125). Oxford: Oxford University Press.

Adelman, I., \& Morris, C.T. (1965). A Factor Analysis of the Interrelationship Between Social and Political Variables and Per Capita Gross National Product. Quarterly Journal of Economics, 79 (4), 555-578. doi:10.2307/1880652

Adelman, I., \& Morris C.T. (1967). Society, Politics and Economic Development. Baltimore: The Johns Hopkins Press.

Adler, J. (1965). Absorptive Capacity and Its Determinants. Washington, DC: Brookings Institution.

Aghion, P., \& Howitt, P. (1992). A Model of Growth Through Creative Destruction. Econometrica, 60 (2), 323-351. doi:10.2307/2951599

Aghion, P., \& Howitt, P. (1998). Endogenous Growth Theory. Cambridge, MA: MIT Press.

Almeida, R., \& Fernandes, A.M. (2008). Openness and Technological Innovations in Developing Countries: Evidence from Firm-Level Surveys. Journal of Development Studies, 44 (5), 701-727. doi:10.1080/00220380802009217

Ames, E., \& Rosenberg, N. (1963). Changing Technological Leadership and Industrial Growth, Economic Journal, 73 (289), 13-31. doi: $10.2307 / 2228401$

Amsden, A.H. (1989). Asia's Next Giant: South Korea and Late Industrialization. New York: Oxford University Press.

Archibugi, D., \& Coco, A. (2004). A New Indicator of Technological Capabilities for Developed and Developing Countries (ArCo). World Development, 32 (4), 629-654. doi:10.1016/j.worlddev.2003.10.008 
Archibugi, D., \& Coco, A. (2005). Measuring Technological Capabilities at the Country Level: a Survey and a Menu for Choice. Research Policy, 34 (2), 175-194. doi:10.1016/j.respol.2004.12.002

Bell, M., \& Pavitt, K. (1993). Technological Accumulation and Industrial Growth: Contrasts Between Developed and Developing Countries. Industrial Corporate Change, 2 (1), 157-210. doi:10.1016/j.respol.2004.12.002

Benavente, J.M. (2006). The Role of Research and Innovation in Promoting Productivity in Chile. Economics of Innovation and New Technology, 15 (45), 301-315. doi:10.1080/10438590500512794

Blankley, W., Scerri, M., Molotja, N., \& Saloojee, I. (2006). Measuring Innovation in OECD and Non-OECD Countries. Cape Town: HSRC Press.

Botero, J. C., Djankov, S., La Porta, R., Lopez-de-Silanes, F., \& Shleifer, A., (2004). The Regulation of Labor. Quarterly Journal of Economics, 119 (4), 1339-1382. doi:10.1162/0033553042476215

Chudnovsky, D., López, A., \& Pupato, G. (2006). Innovation and Productivity in Developing Countries: a Study of Argentine Manufactuirng Firms's Behaviour (1992-2001). Research Policy, 35 (2), 266-288. doi:10.1016/j.respol.2005.10.002

Cincera, M., \& van Pottelsberghe de la Potterie, B. (2001). International R\&D Spillovers: A Survey. Cahiers Economiques de Bruxelles, 169, 3-32.

Coe, D.T., \& Helpman, E. (1995). International R\&D Spillovers. European Economic Review, 39 (5), 859-887. doi:10.1016/0014-2921(94)00100-E

Coe, D.T., Helpman, E., \& Hoffmaister, A.W. (1997). North-South R\&D Spillovers. Economic Journal, 107 (440), 134-49.

Cohen, W.M., \& Levinthal, D.A. (1990). Absorptive Capacity: a New Perspective on Learning and Innovation. Administrative Science Quarterly, 35 (1), 128-152. doi:10.2307/2393553

Crépon, B., Duguet, E., \& Mairesse, J. (1998). Research and Development, Innovation and Productivity: an Econometric Analysis at the Firm Level. Economics of Innovation and New Technology, 7 (2), 115-158. doi:10.1080/10438599800000031

Crespi, G., \& Peirano, F. (2007). Measuring Innovation in Latin America: What We Did, Where We Are and What We Want to Do. Proceeding From the Conference on Micro Evidence on Innovation in Developing Countries (MEIDE), UNU-MERIT Working Papers, Maastricht, The Netherlands.

Dahlman, C.J., Ross-Larson, B., \& Westphal, L. (1987). Managing Technological Development. Lessons from the Newly Industrialized 
Countries. World Development, 15 (6), 759-775. doi:10.1016/0305$\underline{750 \times(87) 90058-1}$

Damijan, J.P., Kostevc, C., \& Rojec, M. (2008). Innovation and Firm's Productivity Growth in Slovenia: Sensitivity of Results to Sectoral Heterogeneity and to Estimation Method? Evidence from Slovenia. LICOS Discussion Paper, 203/2008.

De Negri, J.A., Esteves, L., \& Freitas, F. (2007). Knowledge Production and Firm Growth in Brazil. Working Papers 0020, Universidade Federal do Paraná, Department of Economics.

Djankov, S., La Porta, R., Lopez-de-Silanes, F., \& Shleifer, A. (2002). The Regulation of Entry. Quarterly Journal of Economics, 117 (1), 1-37. doi:10.1162/003355302753399436

Djankov, S., La Porta, R., Lopez-de-Silanes, F., \& Shleifer, A. (2003). Courts. Quarterly Journal of Economics, 118 (2), 453-517. doi:10.1162/003355303321675437

Dosi, G., Pavitt, K., \& Soete, L.G. (1990). The Economics of Technical Change and International Trade. London: Harvester Whetsheaf.

Eaton, S., \& Kortum, S. (1999). International Technology Diffusion: Theory and Measurement. International Economic Review, 40 (3), 537-570. doi:10.1111/1468-2354.00028

Eckaus, R.S. (1973). Absorptive Capacity as a Constraint Due to Maturation Processes. In J., Bhagwati, \& R.S., Eckaus (Eds.), Development and Planning: Essays in Honour of Paul Rosenstein-Rodan (pp.79-108). London: Allen \& Unwin.

Edquist, C. (2004). Systems of Innovation: Perspectives and Challenges. In J., Fagerberg, D. Mowery, \& R. Nelson (Eds.), The Oxford Handbook of Innovation (pp. 181-208). Oxford: Oxford University Press.

Fagerberg, J. (1987). A Technology Gap Approach to Why Growth Rates Differ. Research Policy, 16 (2-4), 87-99. doi:10.1016/0048-7333(87)90025-4

Fagerberg, J. (1988). International Competitiveness. Economic Journal, 98 (391), 355-374. doi:10.2307/2233372

Fagerberg, J., \& Verspagen, B. (2002). Technology-Gaps, InnovationDiffusion and Transformation: an Evolutionary Interpretation. Research Policy, 31 (8-9), 1291-1304. doi:10.1016/S0048-7333(02)00064-1

Fagerberg, J. (2003). Schumpeter and the Revival of Evolutionary Economics: an Appraisal of the Literature. Journal of Evolutionary Economics, 13 (2), 125-159. doi:10.1007/s00191-003-0144-1

Fagerberg, J. (2004). Innovation: A Guide to the Literature. In J., Fagerberg, D., Mowery, R., Nelson, (Eds.), The Oxford Handbook of Innovation (pp.126). Oxford: Oxford University Press. 
Fagerberg, J., \& Godinho, M. M. (2004) Innovation and Catching-up. In J., Fagerberg, D., Mowery, R., Nelson, (Eds.), The Oxford Handbook of Innovation (pp.514-544). Oxford: Oxford University Press.

Fagerberg, J., Srholec, M., \& Knell, M. (2007). The Competitiveness of Nations: Why Some Countries Prosper While Others Fall Behind. World Development, 35 (10), 1595-1620. doi:10.1016/j.worlddev.2007.01.004

Fagerberg, J., \& Srholec, M. (2008). National Innovation Systems, Capabilities and Economic Development. Research Policy, 37 (9), 14171435. doi:10.1016/j.respol.2008.06.003

Fagerberg, J., Srholec, M., \& Verspagen, B. (2010). Innovation and Economic Development. In B., Hall, \& N., Rosenberg (Eds.), Handbook of the Economics of Innovation (pp.833-872). Vol. II. North Holland, 833-872.

Falk, M. (2008). Effects of Foreign Ownership on Innovation Activities: Empirical Evidence for Twelve European Countries. National Institute Economic Review, 204 (1), 85-97. doi:10.1177/0027950108093762

Figueiredo, P.N. (2006). Introduction. International Journal of Technology Management, 36 (1-2-3), 1-13.

Fransman, M. (1982). Learning and the Capital Goods Sector Under Free Trade: the Case of Hong Kong. World Development, 10 (11), 991-1014. doi:10.1016/0305-750X(82)90037-7

Fransman, M., \& King, K. (Eds.), (1984). Technological Capability in the Third World. London: MacMillan.

Freeman, C. (1987). Technology Policy and Economic Performance: Lessons from Japan. London: Pinter.

Furman, J.L., Porter, M.E., \& Stern, S. (2002). The Determinants of National Innovative Capacity. Research Policy, 31 (6), 899-933. doi:10.1016/S0048-7333(01)00152-4

Furman, J.L. \& Hayes, R. (2004). Catching up or Standing Still? National Innovative Productivity among 'Follower' Countries. Research Policy, 33 (9), 1329-1354. doi:10.1016/j.respol.2004.09.006

Gerschenkron, A. (1962). Economic Backwardness in Historical Perspective, Cambridge, Massachusetts: The Belknap Press.

Goedhuys, M. (2007a). Learning, Product Innovation, and Firm Heterogeneity in Developing Countries: Evidence from Tanzania. Industrial and Corporate Change, 16 (2), 269-292. doi:10.1093/icc/dtm003

Goedhuys, M. (2007b). The Impact of Innovation Activities on Productivity and Firm Growth: Evidence from Brazil. UNU-MERIT Warking Papers, 2007-002. Maastricht, The Netherlands.

Goedhuys, M., Janz, N., \& Mohnen, P. (2008a). What Drives Productivity in Tanzanian Manufacturing Firms: Technology or Business 
Environment? European Journal of Development Research, 20 (2), 199-218. doi:10.1080/09578810802060785

Goedhuys, M., Janz, N., \& Mohnen, P. (2008b). Knowledge-based Productivity in Low-tech Industries: Evidence from Firms in Developing Countries. UNU-MERIT Working Paper, 2008-007. Maastricht, The Netherlands.

Goedhuys, M., \& Srholec, M. (2009). Searching for the Link Between Innovation Capabilities and Productivity in Firms: How Much Do the National Framework Conditions Matter? Proceeding from the 7th Globelics Conference. Dakar, Senegal.

Gonçalves, E., Lemos, M.B., \& De Negri, J.A. (2007). Drivers of Technological Innovation in Argentina and Brazil. In J.A. De Negri, \& L.M., Turchi (Eds.), Technological Innovation in Brazilian and Argentine firms (pp.177-202). Institute for Applied Economic Research (IPEA), Brasília.

Görg, H., \& Greenaway, D. (2004). Much Ado about Nothing? Do Domestic Firms Really Benefit from Foreign Direct Investment? The World Bank Research Observer, 19 (2), 171-197. doi:10.1093/wbro/1kh019

Görg, H., \& Strobl, E. (2001). Multinational Companies and Productivity Spillovers: a Meta-Analysis. Economic Journal, 111 (475), 723-739. doi:10.1111/1468-0297.00669

Griffith, R., Redding, S., \& Van Reenen, J. (2004). Mapping the Two Faces of R\&D: Productivity Growth in a Panel of OECD Industries. Review of Economics and Statistics, 86 (4), 883-895. doi:10.1162/0034653043125194

Grossman, G.M., \& Helpman, E. (1991). Innovation and Growth in the Global Economy. Cambridge, Massachusetts: MIT Press.

Hanson, P., \& Pavitt, K. (1987). The Comparative Economics of Research, Development and Innovation in East and West: a Survey. Chur: Harwood Academic Publishers.

Hegde, D., \& Shapira, P. (2007). Knowledge, Technology Trajectories, and Innovation in a Developing Country Context: Evidence from a Survey of Malaysian Firms. International Journal of Technology Management, 40 (4), 349-370. doi:10.1504/IJTM.2007.015757

Hobday, M. (1995). East Asian Latecomer Firms. World Development, 23 (7), 1171-1193. doi:10.1016/0305-750X(95)00035-B

Islam, N. (2003). What Have We Learnt from the Convergence Debate? Journal of Economic Surveys, 17 (3), 309-362. doi:10.1111/1467-6419.00197

Jaklic, A., Damijan, J.P., \& Rojec, M. (2008). Innovation Cooperation and Innovation Activity of Slovenian Enterprises. LICOS Discussion Paper, 201/2008. 
Jaramillo, H., Lugones, G., \& Salazar, M. (2001). Bogota Manual. RICYT/OAS/CYTED/COLCIENCIAS/OCYT: Latin America.

Jefferson, G.H., Huamao, B., Xiaojing, G., \& Xiaoyun, Y. (2006). R\&D Performance in Chinese Industry. Economics of Innovation and New Technology, 15 (4-5), 345-366. doi:10.1080/10438590500512851

Karray, Z., \& Kriaa, M. (2008). Innovation and R\&D Investment of Tunisian Firms: a Two Regimes Model with Selectivity Correction. ERF 15th Annual Conference - Equity and Economic Development. Cairo, Egypt.

Katz, J.M. (1984). Domestic Technological Innovations and Dynamic Comparative Advantage. Journal of Development Economics, 16 (1-2), 1337. doi:10.1016/0304-3878(84)90100-7

Kaufmann, D., Kraay, A., \& Mastruzzi, M. (2003). Governance Matters III: Governance Indicators for 1996-2002. Policy Research Working Paper No. 3106. New York: World Bank.

Keller, W. (1996). Absorptive Capacity: on the Creation and Acquisition of Technology in Development. Journal of Development Economics, 49 (1), 199-227. doi:10.1016/0304-3878(95)00060-7

Keller, W. (2004). International Technology Diffusion. Journal of Economic Literature, 42 (3), 752-782. doi:10.1257/0022051042177685

Keller, W. (2010). International Trade, Foreign Direct Investment, and Technology Spillovers. In B., Hall, \& N. Rosenberg (Eds.), Handbook of the Economics of Innovation (pp.793-829), North Holland.

King, R.G., \& Levine., R. (1993). Finance and Growth: Schumpeter Might Be Right. Quarterly Journal of Economics 108 (3), 717-737. doi:10.2307/2118406

Kim L. (1980). Stages of Development of Industrial Technology in a Developing Country: a Model. Research Policy, 9 (3), 254-277. doi:10.1016/0048-7333(80)90003-7

Kim, L. (1997). Imitation to Innovation: The Dynamics of Kerea's Technological Learning. Harvard: Harvard Business School Press.

Kline, S.J., \& Rosenberg, N. (1986). An Overview of Innovation. In R., Landau, \& N., Rosenberg (Eds.), The Positive Sum Strategy: Harnessing Technology for Economic Growth (pp. 275-304). Washington D.C.: National Academy Press.

Krueger, A., \& Lindahl., M. (2001). Education for Growth: Why and for Whom? Journal of Economic Literature, 39 (4), 1101-1136.

Lall, S. (1987). Learning to Industrialize: the Acquisition of Technological Capability by India. London: Macmillan Press.

Lall, S. (1992). Technological Capabilities and Industrialization. World Development, 20 (2), 165-186. doi:10.1016/0305-750X(92)90097-F 
Lee, C. (2004). The Determinants of Innovation in the Malaysian Manufacturing Sector: an Econometric Analysis at the Firm Level. ASEAN Economic Bulletin, 21 (3), 319-329. doi:10.1355/AE21-3E

Lee, K., \& Kang, S-M. (2007). Innovation Types and Productivity Growth: Evidence from Korean Manufacturing Firms. Global Economic Review, 36 (4), 343-359. doi:10.1080/12265080701694512

Landes, D. (1998). The Wealth and Powerty of Nations. London: Abacus.

La Porta, R., López-de-Silanes, F., Pop-Eleches, C., \& Schleifer, A. (2004). Judicial Checks and Balances. Journal of Political Economy, 112 (2), 445470. doi:10.1086/381480

Levine, R. (1997). Financial Development and Economic Growth: Views and Agenda. Journal of Economic Literature, 35 (2), 688-726.

Levine, R., \& Zervos, S. (1998). Stock Markets, Banks, and Economic Growth. American Economic Review, 88 (3), 537-558.

Lundvall, B.A., (Ed.) (1992). National Systems of Innovation: Towards a Theory of Innovation and Interactive Learning. London: Pinter Publishers.

Masso, J., \& Vahter, P. (2008). Technological Innovation and Productivity in Late-transition Estonia: Econometric Evidence from Innovation Surveys. European Journal of Development Research, 20, pp. 240-261. doi:10.1080/09578810802060751

Nelson, R., (1993). National Innovation Systems: a Comparative Analysis. New York: Oxford University Press.

OECD (2005). Oslo Manual. $3^{\text {rd }}$ edition Paris: OECD.

Oerlemans, L.A.G, \& Pretorius, M.W. (2006). Some Views on Determinants of Innovative Outcomes of South African Firms: an Exploratory Analysis Using Firm-level Data. South African Journal of Science, 102 (1112), 589-593.

Ohkawa, K., \& Rostovsky, H. (1974). Japanese Economic Growth. Stanford: Stanford University Press.

Pamukçu, T. (2003). Trade Liberalization and Innovation Decisions of Firms: Lessons from Post-1980 Turkey. World Development, 31 (8), 14431458. doi:10.1016/S0305-750X(03)00087-1

Park, W.G. (2008). International Patent Protection: 1960-2005. Research Policy, 37 (4), 761-766. doi:10.1016/j.respol.2008.01.006

Putnam, R. (1993). Making Democracy Work. Princeton: Princeton University Press.

Raffo, J., Lhuillery, S., \& Miotti, L. (2008). Northern and Southern Innovativity: a Comparison Across European and Latin American Countries. European Journal of Development Research, 20, 219-239. doi:10.1080/09578810802060777 
Rodríguez, F., \& Rodrik, D. (1999). Trade Policy and Economic Growth: a Sceptic's Guide to the Cross-National Evidence. CEPR. Discussion Paper 2143.

Rodrik, D., Subramanian, A., \& Trebbi, F. (2004). Institutions Rule: the Primacy of Institutions Over Geography and Intergration in Economic Development. Journal of Economic Growth, 9 (2), 131-165. doi:10.1023/B:JOEG.0000031425.72248.85

Romer, P.M. (1986). Increasing Returns and Long-run Growth. Journal of Political Economy, 94 (5), 1002-1037. doi:10.1086/261420

Romer, P.M. (1990). Endogenous Technological Change, Journal of Political Economy, 98 (5), 71-102. doi:10.1086/261725

Romijn, H. (1999). Acquisition of Technological Capabilities in Small Firms in Developing Countries. Basingstoke: Macmillan Press.

Roud, V. (2007). Firm-level Research on Innovation and Productivity: Russian Experience. Proceeding from the Conference on Micro Evidence on Innovation in Developing Countries (MEIDE), UNUMERIT Warking Papers, Maastricht, The Netherlands.

Schumpeter, J. (1934). The Theory of Economic Development. Cambridge, Massachusetts: Harvard University Press.

Shin, J-S. (1996). The Economics of the Latecomers: Catching-up, Technology Transfer and insTitutions in Germany, Japan and South Korea. London: Routledge.

Smith, K. (2004). Measuring Innovation. In J., Fagerberg, D., Mowery, \& R.R., Nelson (Eds.), The Oxford Handbook of Innovation. Oxford: Oxford University Press.

Solow, R.M. (1956). A Contribution to the Theory of Economic Growth. Quarterly Journal of Economics, 70 (1), 65-94. doi:10.2307/1884513

Srholec, M. (2007). A Multilevel Approach to Geography of Innovation. University of Oslo, Working Papers on Innovation Studies, Centre for Technology, Innovation and Culture, University of Oslo, revised Mar 2009.

Srholec, M. (2008). A Multilevel Analysis of Innovation in Developing Countries. UNU-MERIT Working Paper Series 040, United Nations University, Maastricht Economic and Social Research and Training Centre on Innovation and Technology.

Srholec, M. (2009). Does Foreign Ownership Facilitate Cooperation on Innovation? Firm-level Evidence from the Enlarged European Union. European Journal of Development Research, 21, 47-62. doi:10.1057/ejdr.2008.9 
Sung, T-K., \& Carlsson, B. (2007). Network Effects, Technological Opportunity, and Innovation: Evidence from the Korean Manufacturing Firms. Asian Journal of Technology Innovation, 15 (1), 91108.

Teitel, S. (1981). Towards an Understanding of Technical Change in Semiindustrialized Countries. Research Policy, 10 (2), 127-147. doi:10.1016/0048-7333(81)90002-0

Temple, J., \& Johnson, P.A. (1998). Social Capability and Economic Growth. Quarterly Journal of Economics, 113 (3), 965-990. doi:10.1162/003355398555711

UNDP (2004). Human Development Report. New York: UNDP.

UNU-INTECH (2004). Designing a policy-relevant innovation survey for NEPAD. Maastricht: UNU-INTECH.

Verspagen, B. (1991). A New Empirical Approach to Catching up or Falling Behind. Structural Change and Economic Dynamic, 2 (2), pp. 359380. doi:10.1016/S0954-349X(05)80008-6

Woolcock, M., \& Narayan, D. (2000). Social Capital: Implications for Development Theory. Research and Policy. World Bank Research Observer, 15 (2), 225-250.

Wooster, R.B., \& Diebel, D.S. (2006). Productivity Spillovers from Foreign Direct Investment in Developing Countries: A Meta-Regression (April 23, 2006). Available at SSRN: $\underline{\text { http://ssrn.com/abstract }=898400}$

World Bank (2003). Productivity and Investment Climate Survey (PICS): Implementation Manual. New York: World Bank.

World Bank (2008). World Development Indicators 2007. New York: World Bank.

World Bank (2009). Doing Business Indicators. World Bank: New York.

World Values Survey Association (2006). World Values Survey 1981-2004 Official Aggregate v.20060423. World Values Survey Association (www.worldvaluessurvey.org). Aggregate File Producer: ASEP/JDS, Madrid. 